\title{
Gyorsreagálás a pandémiára, ellátásbiztonság
}

\author{
Greiner István \\ Richter Gedeon Nyrt., Budapest, Magyarország \\ Beérkezett: 2021. május 9.; Elfogadva: 2021. július 7.
}

\begin{abstract}
Összefoglalás
A tavalyi évben kitört COVID-19 pandémia jelentős kihívások elé állította a világot. Nem pusztán a kormányok és az egészségügyi rendszerek szembesültek új, békeidőben eddig még nem gyakorolt feladatokkal, de a tudományos világnak is át kellett tekinteni mind a régi, mind a legmodernebb eszközöket ahhoz, hogy a vírus terjedésének, a betegek szenvedéseinek, a tömeges halálozásoknak végre véget lehessen vetni. Habár a járványnak még messze nincsen vége, és egyre újabb és újabb mutánsok ütik fel a fejüket a világ legkülönbözőbb részein, mégis azokat a tanulságokat, melyek már összegyúltek a gyógyszeripar területén, érdemes összefoglalni. Talán még ennél is fontosabb azonban, hogy azokat a hiányokat, amelyeket még be kell pótolni, szintén megemlítsük, hogy ezzel is segítsük az újabb hullámok vagy járványok leküzdését.
\end{abstract}

Kulcsszavak: SARS-CoV-2, COVID-19, gyógyszeripar, vakcina, gyógyszer, járvány

\section{Rapid response to pandemia, supply security \\ Istvan Greiner}

Gedeon Richter Plc., Budapest, Hungary

\begin{abstract}
Summary
During the last 12 months the most serious issue was the SARS-CoV-2 virus generated pandemia around the world. There is no country which could be more or less intact and a huge amount of resources was sacrificed to rescue people from the fatal outcome of this disease. When it started a year ago or more, there were doubts about its future but later it was realised that this is an epidemic occurring worldwide, crossing international boundaries, and affecting a large number of people. According to the WHO, today the number of confirmed cases is about 157.8 million, confirmed deaths are 3.3 million and 1.2 billion vaccine doses have been administered. These numbers clearly show how important it is to elaborate the reaction of the pharma industry and investigate how to ensure safe drug supply for patients in every country. The topics discussed below are the basic and unique features of the SARS-CoV-2 virus, the pandemia generated by it, and the role of the Hungarian pharma industry, especially Gedeon Richter plc, during this critical period. On one hand the author explains how the spread of virus can be decreased in general and at a production facility like Richter, and on the other hand R\&D activity of the Company aiming to cure patients suffering from COVID-19 infection. Consortia including universities, academia and industrial entities made a substantial impact on handling this terrible epidemic. Gedeon Richter plc, the biggest and only independent Hungarian pharma company, in keeping with its roots started small molecule R\&D to make favipiravir and remdesivir available to clinics. The latter production is a very difficult one but using its background in chemistry Richter was able to manage all R\&D and industrial scale up activities in six months. Moreover, it has filed two patent applications about its new, more feasible and economical process steps justifying its innovative attitude. As a final conclusion it is stated that for the safe supply of necessary medication one critical step is missing from the capabilities of the Hungarian pharma industry, the vaccine R\&D and production.
\end{abstract}

Keywords: SARS-CoV-2, COVID-19, pharma industry, vaccine, medicine, pandemia 


\section{Bevezetés}

Régóta nem kísérte akkora figyelem a betegségek leküzdésével foglalkozó szakemberek munkáját, mint napjainkban. A jelenlegi COVID-19 világjárvány, melynek nagyszámú halálos áldozata nap mint nap megdöbbenti a hírfogyasztó szakmai és nem szakmai közösséget, jelentős kihívás elé állítja a társadalmakat. Az, hogy melyik ország, melyik ágazat hogyan reagál ezekre a kihívásokra, milyen feladatok megoldásába kezd bele, döntően befolyásolja a járvány hosszát és súlyosságát is, mind a közvetett, mind a közvetlen hatásokat figyelembe véve. Ebben a publikációban arra teszek kísérletet, hogy az elmúlt egy év tapasztalatait összegezve megmutassam, milyen elvek mentén és milyen feladatok megvalósításával tud egy gyógyszeripari cég reagálni a pandémia következtében megjelenő feladatokra, hogyan tudja szolgálni a járvány leküzdését rövid, közép- és hosszú távon.

\section{A SARS-CoV-2 (COVID-19) vírus és a járvány sajátosságai}

Talán már a laikus közönség is pontosan tudja, hogy milyen sajátságokkal bír ez az új, COVID-19-cel jelzett vírus, mindazonáltal fontosnak tartom a múködésének bemutatását, hiszen a beavatkozási lehetőségek is csak így válhatnak érthetővé. A COVID-19 az RNS vírusok közé tartozik, örökítőanyaga a membránburokban tárolt RNS (ribonukleinsav). A gazdaszervezetbe egy sejtfelszíni fehérjével történő kötődés után jut be, akár többféleképpen is biztosítva az örökítőanyag citoplazmába történő kerülését (Baraniuk 2020). A sejtbe jutás legfontosabb kapcsolódási pontja az úgynevezett ACE2 sejtfelszíni receptor, de ez a kötődés önmagában még nem elég, egyéb enzimek aktivizálódása is szükséges ahhoz, hogy a vírusban lévő RNS molekulák a sejtbe jussanak, és ott a sejt energiájának felhasználásával elkezdjék legyártatni az újabb vírusok létrehozásához szükséges enzimeket és egyéb összetevőket. Ezek azután a megfelelő aggregációval kialakítják az új vírusrészecskéket, és a sejt elpusztulásakor, ami mindenképpen bekövetkezik a normálistól eltérő sejtfunkciók miatt, kikerülnek a környezetbe, a keringésbe, lehetőséget kapva az újabb sejtek megfertőzésére. Ebben a folyamatban ugyan egy vírus megsemmisül, viszont sokkal több új vírus keletkezik. Ennek a folyamatnak a során jöhetnek létre a mutációk is, melyek közül a vírus szempontjából optimálisak hatékonyabban tudják megvalósítani a vírus fennmaradását, sokszorozódását.

A szervezet diszfunkcionális és elhalt sejtjei elindítják a szervezet gyulladásos folyamatait, melyek egyik jellemzője a gyulladásos citokinek megjelenése, illetve koncentrációjuk jelentős megemelkedése. A gyulladásos folyamatokban több pozitív visszacsatolású is van, ezek magukban rejtik egy olyan tünetegyüttes megjelenését, mely fatális kimenetelű lehet. Ezt a tünetegyüttest hívják szakmai körökben citokinviharnak, és elkerülése a
COVID-19 betegek túlélésének egyik fó kritériuma (Szekanecz-Constantin 2020).

Természetesen a folyamatok nem hagyják érintetlenül a szervezet immunrendszerét sem. Amennyiben a szervezet már az első vírusrészecskéket idegen anyagnak érzékeli, azonnal megkezdődnek a védekező folyamatok, melyeket tovább erősít az idegen részecskék számának növekedése és a párhuzamosan megjelenő gyulladásos folyamatok. Akár egy sajátos háborúnak is tekinthetjük azokat a folyamatokat, amelyek ilyenkor (és más fertőzések esetében is) a vírusok és az immunrendszer között zajlanak le. Amennyiben a vírusok számának növekedését meg tudja haladni az immunrendszer víruselimináló képessége, akkor a fertőzött személy meg tud gyógyulni, ellenben, ha ez fordítva történik, akkor a beteg állapota súlyosbodni fog. Amennyiben a vírusfertőzésen túl egyéb kórokozók is megjelennek a szervezetben (pl. a tüdőgyulladást okozó/erősítő baktériumok), akkor már a szervezet energiáit fokozottan felhasználó küzdelem többfrontossá válik, amire még ráépülhet maga a citokinvihar is, sokat súlyosbító tényezőként. Ezekben az esetekben az orvos feladata kiszélesedik, az egyes tünetek többrétű okait többszörös terápiával kell kezelnie, sajnos a gyógyulás egyre csökkenő esélyével. Talán az is jobban érthetó így, hogy egy alapbetegségekkel terhelt szervezet miért is tud kevésbé ellenállni egy ilyen fertőzésnek, miért gyakoribbak ilyenkor a fatális kimenetek.

A vírusfertőzéssel kialakuló, akár halálos végkimenetellel járó betegség okozásán túl sajnos ennek a kórokozónak van még a járvány terjedését elősegítő több hátrányos tulajdonsága. Az első ilyen a potenciálisan hosszú lappangási idő. Jelenlegi tudásunk szerint átlagosan 5-6 nap telik el a fertőződés és a tünetek megjelenése között, azonban ez egyes esetekben akár 14 napra is elnyúlhat (Yu et. al. 2020; Lauer et al. 2020). Érthető, hogy a hoszszú lappangási idő segíti a vírus terjedését, tovább fokozva ezt, ha valaki a már észlelt tünetei ellenére nem tartja be a szeparációs szabályokat. Szintén fokozza a járvány erősségét, hogy cseppfertőzés útján jól terjed, egyes szakértők szerint zárt térben egy fertőzött akár 100 új fertőződést is okozhat (Szlávik 2021).

\section{A gyógyszeripar szerepe pandémia idején}

Nagyon sok tévképzet alakult ki az emberekben a gyógyszeriparról, kezdve a haszonleséstól egészen a kitalált betegségekig. Az ezek ellen folyó szüntelen küzdelem a pandémia idején sem szúnhet meg, de talán ez a legkevésbé fontos küldetése ennek az iparágnak ilyen vészterhes időkben. Mindenekelőtt azt kell kiemelni, hogy a vírusfertőzéstől független betegségek ebben az időszakban is ugyanúgy fennállnak és ugyanúgy kezelésre, terápiára szorulnak, mint a járvány előtt. Ezért a gyógyszergyárak elsődleges feladata ilyenkor is a szokásos ellátásbiztonság fenntartása. Ezekben a hónapokban is szükség van vérnyomáscsökkentőkre, fájdalomcsillapí- 
tókra, pszichiátriai betegségek kezelésére, utóbbira talán még inkább, citosztatikumokra, és így tovább.

Ez már önmagában is indokolja, hogy a gyógyszeripar, gyógyszer-kereskedelem és értékesítés a kritikus infrastruktúra részeként kerül definiálásra, és a járvány legnehezebb időszakában honvédelmi törzs irányítása alá is kerülhetnek ezek a cégek. A gyógyszergyárak termeléskiesése ugyanis nem pusztán gazdasági haszon csökkenésével jár, hanem akár a közegészségügy további romlását is okozhatja. Különösen fontos ezt ezen a szemüvegen keresztül nézni olyankor, amikor az országok bezárkóznak, a nemzetközi áruforgalom lecsökken, és minden kormány, el nem ítélhetó módon, a saját országát helyezi előtérbe a járvány káros hatásának mérséklésekor, azaz kritikus területeken könnyen áruhiány léphet fel. Ilyenkor az egészségügyi intézményekhez hasonlóan a gyógyszergyárak is a legelsők között hozzák meg azokat az intézkedéseket, melyek a termelő egységeken belüli vírusterjedést minimalizálják, a személyes higiéniát előtérbe helyezik és a kontaktusszámot csökkentik. Természetesen utóbbi nem jelentheti olyan területek múködésének korlátozását, amelyek a gyártást, annak anyagellátását, biztonságát és a minőség-ellenőrzést érintik. Az intézkedéseket, szigorításokat a járványhelyzet rosszabbodásával párhuzamosan, vagy akár preventíven kell bevezetni, illetve észszerü késleltetéssel kivezetni. Fontos továbbá a vészhelyzeti teendők korai kidolgozása, és adott esetben azok azonnali alkalmazása. Hazai viszonyokat tekintve érdemes még megemlíteni, hogy a normális körülmények között nagy hagyományokkal rendelkező iparágak, így a gyógyszeripar területén is nagyon alacsony volt az otthoni munkavégzés aránya, így az ehhez szükséges informatikai eszközök és háttér is sokszor hiányoztak. Egy évvel ezelőtt ez a probléma hamar cselekvésre késztette a cégeket és szintén azonnali intézkedéseket követelt, melyeket minden iparág sikeresen abszolvált.

\section{A Richter Gedeon Nyrt. pandémiával kapcsolatos tevékenységei}

\section{Általános intézkedések}

A folyamatok könnyebb érthetősége miatt a Richterben történt pandémiacentrikus aktivitások leírásánál mindig jelzem, hogy a vírus terjedésének mely fázisába avatkozik be az adott akció vagy gyógyszer. Így a mindennapi múködés fenntartását célzó általános intézkedések a vírus terjedését és a szervezetbe kerülését igyekeztek megakadályozni. Már tavaly márciusban megtörténtek az első lépések a nagyobb problémák megelőzésére, melyek két nagy csoportba oszthatók, egyfelől a kontaktszám csökkentését célozták, másfelől az egyéni védekezésre fókuszáltak. A Társaság továbbá jelentős figyelmet fordított a beszerzési lánc célirányosabb üzemeltetésére, és így sikerült elkerülni, hogy hiány alakuljon ki nyersanyagokból vagy egyéb készletekből. Ennek és a mun- kavállalók áldozatos munkájának is köszönhető, hogy valamennyi termékünket az összes piacra időben ki tudtuk szállítani.

A Társaságon belül és kívül is a kontaktszámot minimálisra csökkentettük, így a közvetlen, személyes látogatásra épülő promóciós tevékenységet gyakorlatilag minden piacon megszüntettük, és ezeket a tevékenységeket sikeresen átirányítottuk az online csatornákra. Az első belső intézkedéseket már 2020. március 5-én, a két első magyarországi COVID-19-fertőzés hivatalos bejelentésének másnapján meghozta a Társaság vezetése. Ezek közé tartozott, hogy elektronikus úton megküldte munkavállalóinak és kifüggesztette a vállalat közösségi terein az Egészségügyi Világszervezet (WHO) által közzétett ajánlási szabályokat, a közösségi terek fertőtlenítéséről intézkedett, valamint ideiglenes utazási korlátozásokat vezetett be azokkal az országokkal/régiókkal szemben, amelyeket a járvány akkorra már elért. Az utazási korlátozásokat a nemzetközi helyzet alakulásának megfelelő ütemben, az országhatár átlépését szabályozó rendeletekkel párhuzamosan terjesztettük ki. Természetesen a közösségi távolságtartásra vonatkozó rendelkezések is bevezetésre kerültek a belső és külső közösségi tereken, és azokat a munkavállalókat, akik munkaköri kötelességeiket távoli eléréssel is teljesíteni tudták, a Richter otthoni munkára (home office) küldte. A kötelezően munkába járók számára a Társaság arcmaszkokat biztosított, a müszakok szétválasztását adminisztratív eszközökkel támogatta, és valamennyi közösségi téren önállóan múködtethető kézfertőtlenítő berendezéseket állított üzembe.

A járvány súlyosbodásával az informatikai eszközpark szélesítése után a home office gyakorlatát tovább bővítettük, és a belső megbeszéléseket is online csatornára tereltük annak érdekében, hogy minimumra csökkentsük a vállalaton belüli személyes kontaktusok lehetőségét. A tömegközlekedés használatának csökkentése érdekében a munkába bejárni kényszerülő munkavállalók számára a Társaság bevezette a napi elszámolású támogatását a saját tulajdonú gépkocsival történő munkába járásnak.

A Társaság most, a kormányzat által megkezdett lazítás időszakában csak némi időbeli késleltetéssel követi az intézkedések visszavonását, figyelembe véve a termelés és a munkamenetek folyamatos biztosítását. A Társaság vezetése bízik abban, hogy az átoltottság növekedésével a járványügyi intézkedések belátható időn belül felszámolhatók és mielőbb visszatérhetünk a döntően személyes jelenléttel támogatott optimális munkamenethez.

\section{A Richter Nyrt. kutatási és fejlesztési aktivitásai a pandémiás helyzet kezelésére}

A tudományos közélet figyelme már a 2020-as év elején a vírusfertőzés következtében kialakuló betegség(ek) kezelési lehetőségei felé fordult. Míg a vírus terjedésének megakadályozására a közösségek együttes közremúkö- 
désére volt szükség (lezárások, kijárási tilalom, érintkezési szabályok szigorítása, gyülekezések megtiltása, tömegközlekedésben részt vevők viselkedési szabályainak kialakítása stb.), addig a célzott gyógyszerkutatás feladata a hazai szakemberekre hárult. A kormányzat a $\mathrm{K}+\mathrm{F}+\mathrm{I}$ jellegű feladatok támogatására az Innovációs és Technológiai Minisztériumot kérte fel, amely kialakított egy tudományos koordinációt, platformot és támogatási struktúrát, amely segítségével a különböző egyetemi/ akadémiai és ipari kutatók megoszthatták tudásukat és felgyorsíthatták előrehaladásukat. Ennek a platformnak tevőleges részese volt a Richter Nyrt. is.

Amint az már korábban is ismertetésre került, a vírus egy egyedi bejárati „kaput” használ a sejtbe jutáshoz, amely kiváló lehetőséget nyújt a kutatóknak a közbeavatkozásra. Hiszen amennyiben a vírus külső felületén blokkolni tudjuk azokat a fehérjéket, amelyek a sejthez történő kötődésben kulcsszerepet játszanak, akkor meg tudjuk akadályozni a citoplazmába kerülést és az ottani fehérjeszintézist, vírusreplikációt. A hazai kutatócsoportok egyike, az ELTE TTK Immunológia Tanszékén dolgozó kutatók vezetésével konzorcium alakult egy olyan fúziós fehérje létrehozására és gyógyszerré fejlesztésére, mely a fenti követelményeket kielégíti (Kacskovics 2021). Ebben a munkában Társaságunk a megtervezett hatóanyag (biológikum) előállításával és a klinikai minta legyártásával vesz részt. Mivel egy ilyen gyógyszer kifejlesztése sok évig tart, még pandémia idején is, ezért ez az eszköz a járvány hosszú távú kezelésére nyújthat megoldást.

Amennyiben a vírus már bejutott a sejtbe, akkor ott a sejt energiáit és fehérjéit felhasználva kezdi meg a saját sokszorozását, ezzel a sejtet egyébként a pusztulásba hajszolva. Ennek a folyamatnak az egyik fontos motorja a ribonukleinsav (RNS) függő RNS polimeráz enzim, amely a vírus RNS-készletét állítja elő. Mivel ez az enzim csak a fertőzött sejtekben fordul elő, ennek gátlása, blokkolása hatékony fegyver lehet a vírus ellen. A gyógyszerkutatás egyik hagyományos és fontos alapelve az ún. új indikációs tevékenység, amikor egy már kifejlesztett, forgalomba hozott termék hatékonyságát vizsgálják új indikációs területen (drug repositioning, drug repurposing). Ennek a munkának a gyümölcseként már 2020 tavaszán látható volt, hogy két vegyület, az eredetileg a FujiToyama cégnél influenzavírus ellen kifejlesztett favipiravir és a Gilead cégnél Ebola ellen fejlesztett remdesivir hatékonynak mutatkozott a COVID-19-vírus ellen is. Ennek megfelelően a nevében is jelzett kismolekulás kémiai tudásáról méltán híres Richter Gedeon Vegyészeti Gyár Nyrt. is azonnal elindította ezen vegyületek fejlesztését, az elsőt egy konzorciumban, ahol az ipari léptékü gyártás lett a feladata, míg a másodikat, a remdesivirt egyedül tervezte kifejleszteni klinikai vizsgálatra alkalmas fiolás kiszerelésben. A két vegyület szerkezete bonyolultságban jelentősen eltér, míg az első 5 kémiai lépésben előállítható (Guo et al. 2019), addig az utóbbi szintézise az irodalmi leírások szerint 18 lépésből áll (Siegel 2017).
További különbség volt a két vegyület között, hogy míg a favipiravir nevú hatóanyagot tartalmazó gyógyszer szabadalma már lejárt, és így a világ sok országában (pl. Kínában is) szabadon gyártható volt, addig a remdesivir szabadalmi védelme még élt, és csak K+F célból lehetett elöállítani. A Richter a favipiravir konzorciumban reá kirótt feladatot elvégezte, azaz a klinikai vizsgálatokra alkalmas hatóanyagot elóállította és átadta a konzorciumi partnereknek további felhasználás céljából.

A Társaság $\mathrm{K}+\mathrm{F}$ eróforrásainak a remdesivir oldatot tartalmazó, és infúzióban hígítandó fiola klinikai vizsgálatra történő elóallítása minden szempontból lényegesen jelentősebb próbatétel volt. Kiemelésre érdemes, hogy a kémiai tudásáról méltán híres cégnek a soklépéses reakciósort 5 hónap alatt sikerült ipari gyártási léptékben kifejleszteni és gyógyszerhatóanyag minőségben több kg alapanyagot elő is állítani. A javított eljárás egyes lépéseire a Társaság magyar elsőbbségi szabadalmi bejelentéseket is tett (P2000258 és P2000371), így védve meg a kidolgozott szellemi termékeket. Ezzel párhuzamosan zajlott a készítmény fejlesztése, majd ezután a klinikai minta gyártása. A megfeszített munka eredményeképpen október elején, a munka kezdésétől számítva a hatodik hónap végén elkezdődhetett a kifejlesztett anyag klinikai kipróbálása. Itt érdemes megjegyezni, hogy eközben a Gilead cég befejezte a remdesivir COVID-19-fertőzésben zajló klinikai vizsgálatait, és az anyag hatékonynak bizonyult. Ezután mind az USA, mind az európai hatóság engedélyezte a termék veszélyhelyzeti alkalmazását. A klinikai vizsgálatba bevont betegek kezelése minden jelenleg rendelkezésre álló információ szerint hozzájárult a járvány leküzdéséhez, illetve a fertőzéses betegek állapotának javításához.

A Richter Nyrt.-nél végzett sikeres munka azt is jelentette, hogy külső, külföldi beszállítóktól függetlenül így már biztosíthatóvá vált a hazai favipiravir és remdesivir igények rövid távú kielégítése, akár súlyosbodó járványhelyzet idején is.

Amint azt korábban is leírtam már, a betegség utolsó, többségében fatális kimenetelű fázisa az ún. citokinvihar. Ennek kezelésére tipikusan, de nem kizárólagosan a különböző mechanizmussal működő gyulladásgátló szerek alkalmasak. Ezek egyikének, a tocilizumabnak már a pandémia kialakulása előtt megkezdődött a fejlesztése a Richter Nyrt.-n belül, annak Biotechnológiai Üzletágában, amelyet a pandémiás helyzet felgyorsított. Sajnos azonban ez a fejlesztés is csak középtávon hozhat eredményt, mert a gyógyszer felhasználásához szükséges engedély megadása itt is több klinikai vizsgálathoz kötött, melyek akár évekig is eltarthatnak.

Végezetül érdemes megemlíteni még a járványhelyzet megszüntetéséhez leginkább hozzájáruló vakcinafejlesztést és -gyártást mint a gyógyszeripar előtt álló lehetőségek egyik legfontosabb elemét. Sajnos a reális képhez az tartozik hozzá, hogy ma hazánkban egyetlen nagy gyógyszeripari cégnél sem folyik sem vakcinafejlesztés, sem vakcinagyártás. Ennek tudható be az, hogy ezen a 
területen nem tudtunk gyors előrehaladást felmutatni, de biztonságvédelmi szempontból egyértelmüen fontos lenne valamilyen hazai vakcinafejlesztő és -gyártó egység létrehozása, amely megfelelő sebességgel tudna reagálni egy jövőbeli eseményre, és hazánkat, illetve a környező országokat el tudná látni a szükséges oltóanyaggal, akár újabb mutánsok, akár újabb vírusok ellen.

\section{Irodalomjegyzék}

Baraniuk, C. (2020) Receptors for SARS-CoV-2 Present in Wide Variety of Human Cells. TheScientist, https://www.the-scientist.com/ news-opinion/receptors-for-sars-cov-2-present-in-wide-variety-ofhuman-cells-67496 (Letöltve: 2021. 05. 09.)

Guo, Q., Xu, M., Guo, S., Zhu, F., Xie, Y., \& Shen, J. (2019) The complete synthesis of favipiravir from 2-aminopyrazine. Chemical Papers, Vol. 73, pp. 1043-1051.

Kacskovics, I. (2021) Magyar fejlesztésû gyógyszer a COVID ellen. https://www.elte.hu/content/magyar-fejlesztesu-gyogyszer-acovid-ellen.t.22659 (Letöltve: 2021. 05. 09.)
Lauer, S. A., Grantz, K. H., Bi, Q., Jones, F. K., Zheng, Q., Meredith, H. R., ... Lessler, J. (2020) The Incubation Period of Coronavirus Disease 2019 (COVID-19) From Publicly Reported Confirmed Cases: Estimation and Application. Ann. Int. Med., Vol. 172. No. 9. pp. $577-582$.

Siegel, D., Hui, H. C., Doerffler, E., Clarke, M. O., Chun, K., Zhang, L., .. Mackman, R. L. (2017) Discovery and Synthesis of a Phosphoramidate Prodrug of a Pyrrolo[2,1-f ][triazin-4-amino] Adenine C-Nucleoside (GS-5734) for the Treatment of Ebola and Emerging Viruses. J. Med. Chem., Vol. 60. No. 5. pp. 1648-1661.

Szekanecz, Z., \& Constantin, T. (2020) Citokinvihar Covid-19-fertőzésben. https://mta.hu/tudomany_hirei/citokinvihar-covid-19fertozesben-110610 (Letöltve: 2021. 05. 09.)

Szlávik, J. (2021) Szlávik János: egy szuperfertőző maszk nélkül akár 100 embert is megfertőzhet zárt térben. https://budapestkornyeke.hu/szlavik-janos-egy-szuperfertozo-maszk-nelkul-akar100-embert-is-megfertozhet-zart-terben/ (Letöltve: 2021. 05. 09.)

Yu, P., Zhu, J., Zhang, Z., \& Han, Y. (2020) A Familial Cluster of Infection Associated With the 2019 Novel Coronavirus Indicating Possible Person-to-Person Transmission During the Incubation Period. J. Infect. Dis., Vol. 221 No. 11. pp. 1757-1761.

A cikk a Creative Commons Attribution 4.0 International License (https://creativecommons.org/licenses/by-nc/4.0/) feltételei szerint publikált Open Access közlemény, melynek szellemében a cikk bármilyen médiumban szabadon felhasználható, megosztható és újraközölhetö, feltéve, hogy az eredeti szerző és a közlés helye, illetve a CC License linkje és az esetlegesen végrehajtott módositások feltüntetésre kerülnek. 